\title{
Pengendalian 3-Axis Reaction Wheel Satelit LAPAN-TUBSAT A1 Menggunakan Kendali PID Teroptimasi Algoritma Genetika
}

\author{
Yulio Ramadhan, Hari Hadi Santoso, Erna Kusuma W. \\ Program Studi Teknik Fisika, Fakultas Teknik dan Sains, Universitas Nasional \\ Jalan Sawo Manila, Pasar Minggu, Jakarta 12520 \\ Korespondensi: yulio4ramadhan@gmail.com
}

\begin{abstract}
Abstrak. Reaction wheel merupakan aktuator aktif yang digunakan pada subsistem Attitude Determination and Control System (ADCS) Satelit, pada penelitian ini pengendalian reaction wheel disimulasikan dengan menggunakan kendali PID dan penalaan menggunakan Algoritma Genetika dengan populasi awal sebanyak 100 populan, laju crossover 0.8 , konstanta mutasi 0.01 , kriteria penghenti adalah 50 generasi dengan fitness function berdasarkan indeks performansi PID yaitu ITAE. Pengendalian Reaction Wheel pada lingkar tertutupnya dengan kendali PID yang teroptimasi Algoritma Genetika memiliki karakteristik respon transien yaitu rise time 11 detik, setlling time 91 detik, overshoot 33.2\% dengan indeks performansi ITAE sebesar 481.9479. Dengan menggunakan simulator Smart Nanosatellite Attitude Propagator (SNAP) berbasis MATLAB, dilakukan simulasi dinamis menggunakan model 3-axis reaction wheel sebagai aktuatornya. Satelit LAPAN -TUBSAT A1 digunakan sebagai objek pengendalian, dilakukan simulasi dengan menskenariokan bahwa satelit dalam keadaan tumble memiliki inisial kecepatan sudut [ $\left.\begin{array}{lll}0.5 & 0.5 & 0.5\end{array}\right]$ /detik kemudian dilakukan detumbling yaitu membuat kecepatan sudut satelit menjadi $\left[\begin{array}{lll}0 & 0 & 0\end{array}\right]^{\circ} /$ detik. Sumbu roll dan yaw memiliki error yang cukup besar yaitu direntang $1 \mathrm{rad} / \mathrm{s}$ dan $-1 \mathrm{rad} / \mathrm{s}$ sedangkan sumbu pitch memiliki error kecil direntang $1.5 \times 10^{-3} \mathrm{rad} / \mathrm{s}$ dan $-1.5 \times 10^{-3} \mathrm{rad} / \mathrm{s}$.
\end{abstract}

Kata Kunci: Algoritma genetika, ADCS, LAPAN-TUBSAT A1

\section{PENDAHULUAN}

Satelit adalah benda yang mengelilingi atau mengorbit benda lain yang ukuran dan massanya lebih besar. Ada dua jenis satelit yaitu satelit alami dan satelit buatan. Bulan adalah satelit karena bulan mengelilingi atau mengorbit bumi maka bulan disebut sebagai satelit alami bumi. Satelit buatan adalah benda buatan manusia yang diluncurkan ke angkasa dari Bumi menuju orbitnya. Saat ini ada ribuan satelit buatan yang sedang mengorbit bumi dengan berbagai macam tujuan, antara lain satelit komunikasi untuk membantu arus komunikasi dan informasi di Bumi, satelit astronomi untuk mengamati benda-benda luar angkasa, satelit pengamat bumi untuk mengamati kondisi bumi dan orbitnya, satelit navigasi untuk menentukan lokasi sebuah titik dipermukaan bumi, satelit cuaca untuk mengamati cuaca dan iklim bumi, dan satelit mata-mata untuk keperluan perang [1]. Teknologi satelit merupakan salah satu teknologi yang dibutuhkan Indonesia saat ini. Attitude Determination Control System (ADCS) merupakan salah satu dari subsistem satelit, yang bertugas untuk mengetahui dan mengontrol orientasi satelit [2]. Pengendalian orientasi satelit ini sangat penting dalam menjalankan misinya. Misalnya seperti satelit pengamat bumi yang diberi misi oleh stasiun pengendali di bumi untuk mengamati daerah tertentu pada permukaan bumi. Pada penelitian terdahulu yang dilakukan [3] adalah memodelkan persamaan gerak dinamis untuk sebuah satelit dengan menggunakan software simulink dan MATLAB. Simulink dan MATLAB dipilih sebagai simulator model kontrol satelit karena umum digunakan pada industri kontrol dan kedirgantaraan. Sistem kendali yang mereka pilih adalah PID dan gabungan antara Sliding mode dengan PID (Sliding-PID) untuk mendapatkan kendali yang optimal. Penelitian terdahulu lainnya yang dilakukan [4] adalah kendali kelakuan satelit melalui jaringan 
syaraf tiruan (JST). JST ditraining untuk mendapatkan kendali optimal pada controller, kemudian disimulasikan dengan satelit berukuran kecil yang memiliki tiga reaction wheel.

\section{DASAR TEORI}

\section{Attitude Determination and Control System}

Attitude Determination and Control System (ADCS) merupakan salah satu dari subsistem satelit, yang bertugas untuk mengetahui dan mengontrol orientasi satelit [2]. Pengendalian orientasi satelit ini sangat penting ketika satelit diperintahkan untuk mengarahkan alat instrumen-nya kepada titik atau koordinat yang dikehendaki untuk mendapatkan data yang diinginkan. Misalnya seperti satelit pengamat bumi yang diperintahkan oleh stasiun pengendali di bumi untuk mengamati daerah tertentu pada permukaan bumi. Komponen ADCS yaitu meliputi input, controller, aktuator, measurement, dan output. Block diagram dari ADCS ditunjukan pada gambar 1.

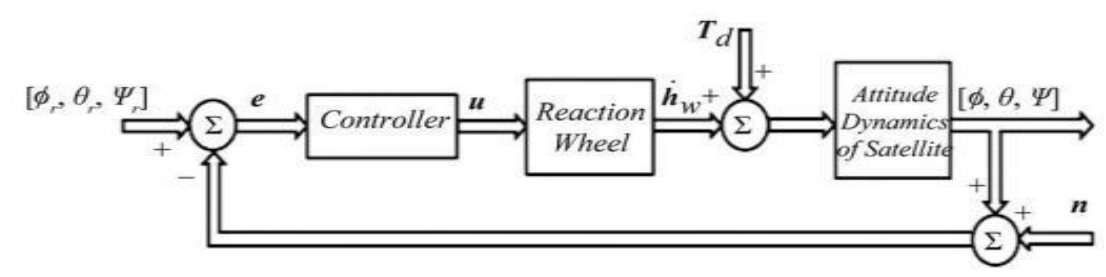

Gambar 1. Blok Diagram ADCS.

\section{Kendali PID}

PID merupakan salah satu sistem kontrol yang sudah lazim digunakan dalam teknologi satelit. Kontrol PID dalam dunia pengendalian terdiri dari tiga macam, yaitu kontrol P (Proportional) yang berfungsi untuk mempercepat respon, kontrol I (Integral) yang berfungsi untuk mengkoreksi dan mereduksi offset, dan kontrol D (Derivatif) yang berfungsi untuk memprediksi dan mereduksi overshoot. Ketiga kontrol ini sebenarnya dapat diaplikasikan menjadi kontrol P (Proportional), kontrol PI (Proportional-Integral), kontrol PD (Proportional-Derivatif), dan kontrol PID (Proportional-Integral-Derivatif) [10]. Namun yang digunakan pada penelitian ini adalah kontrol PID (Proportional-IntegralDerivatif). Kontrol PID secara matematis dirumuskan sebagai berikut:

$M(t)=K_{p}\left[e(t)+\frac{1}{T_{i}} \int e(t)+T_{d} \frac{d e(t)}{d t}\right]$

Di mana: $M(\mathrm{t})$ adalah keluaran kontroler PID, Kp adalah konstanta proportional, Ti adalah waktu integral, $\mathrm{Td}$ adalah waktu derivative dan $\mathrm{e}(\mathrm{t})$ adalah error.

Kontrol PID dimaksudkan supaya memberikan efek mempercepat reaksi sebuah sistem, mengkoreksi dan mereduksi offset, dan memprediksi dan mengurangi overshoot.

\section{Algoritma Genetika}

Algoritma Genetika adalah algoritma pencarian heuristik yang didasarkan atas mekanisme evolusi biologis. Keberagaman pada evolusi biologis adalah variasi dari kromosom antar individu organisme. Variasi kromosom ini akan mempengaruhi laju reproduksi dan tingkat kemampuan organisme untuk tetap hidup. Algoritma genetik pertama kali dikembangkan oleh John Holland dari Universitas Michigan (1975). John Holland mengatakan bahwa setiap masalah yang berbentuk adaptasi (alami maupun buatan) dapat diformulasikan dalam terminologi genetika [11].

Sebuah solusi yang dibangkitkan dalam algoritma genetika disebut sebagai kromosom, sedangkan kromosom-kromosom tersebut disebut sebagai populasi. Sebuah kromosom dibentuk dari komponen-komponen penyusun yang disebut sebagai gen. Kromosom tersebut akan berevolusi secara berkelanjutan yang disebut generasi. Dalam tiap generasi kromosom tersebut dievaluasi tingkat keberhasilan nilai solusinya terhadap masalah yang ingin diselesaikan menggunakan ukuran yang disebut fitness. Untuk memilih kromosom yang tetap dipertahankan untuk generasi selanjutnya dilakukan proses yang disebut seleksi. Proses seleksi kromosom menggunakan konsen aturan evolusi Darwin, yaitu kromosom 
yang mempunyai nilai fitness tinggi akan memiliki peluang lebih besar untuk terpilih lagi pada generasi selanjutnya.

Kromosom baru disebut dengan offspring, dibentuk dengan cara perkawinan antar kromosom dalam satu generasi yang disebut sebagai proses cross-over. Jumlah kromosom dalam populasi yang mengalami cross-over ditentukan oleh parameter yang disebutkan dengan cross-over rate. Mekanisme perubahan susunan untuk penyusun makhluk hidup akibat adanya faktor alam yang disebut dengan mutasi direpresentasikan sebagai proses berubahnya satu lebih nilai gen dalam kromosom dengan suatu nilai acak. Jumlah gen dalam populasi yang mengalami mutasi ditentukan oleh parameter mutation-rate. Adapun diagram alir dari proses algoritma genetika seperti pada gambar 2.

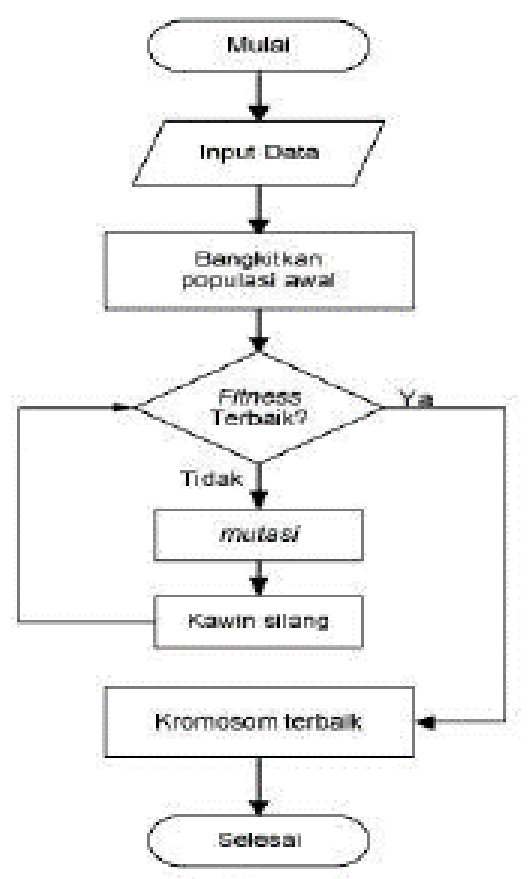

Gambar 2. Diagram Alir Algoritma Genetika.

LAPAN-TUBSAT A1

LAPAN-TUBSAT adalah sebuah satelit mikro yang dikembangkan Lembaga Penerbangan dan Antariksa Nasional (LAPAN) bekerja sama dengan Universitas Teknik Berlin (Technische UniversitÃăt Berlin; TU Berlin). Wahana ini dirancang berdasarkan satelit lain bernama DLR-TUBSAT, namun juga menyertakan sensor bintang yang baru.

Tabel 1. Sifat Massa Satelit LAPAN-TUBSAT A1

\begin{tabular}{|l|l|l|l|}
\hline Jenis & Arah & Besar & Satuan \\
\hline Massa Total & & 54,7 & kg \\
\hline \multirow{4}{*}{ Pusat massa } & $\mathrm{X}$ & 215 & $\mathrm{~mm}$ \\
\cline { 2 - 4 } & $\mathrm{Y}$ & 129 & $\mathrm{~mm}$ \\
\cline { 2 - 4 } & $\mathrm{Z}$ & 218 & $\mathrm{~mm}$ \\
\hline \multirow{4}{*}{ Momen Inersia } & $\mathrm{Ixx}$ & 1,386 & $\mathrm{~kg} \cdot \mathrm{m} 2$ \\
\cline { 2 - 4 } & $\mathrm{Iyy}$ & 2,062 & $\mathrm{~kg} \cdot \mathrm{m} 2$ \\
\cline { 2 - 4 } & $\mathrm{Izz}$ & 1,441 & $\mathrm{~kg} \cdot \mathrm{m} 2$ \\
\cline { 2 - 4 } & $\mathrm{Ixz}$ & 0,0063 & $\mathrm{~kg} \cdot \mathrm{m} 2$ \\
\cline { 2 - 4 } & $\mathrm{Iyz}$ & $-0,003$ & $\mathrm{~kg} \cdot \mathrm{m} 2$ \\
\hline \multirow{4}{*}{$\begin{array}{l}\text { Principal Axis } \\
\text { Orincipal }\end{array}$} & $\mathrm{I} 1$ & 2,064 & $\mathrm{~kg} \cdot \mathrm{m} 2$ \\
\cline { 2 - 4 } & $\mathrm{I} 2$ & 1,481 & $\mathrm{~kg} \cdot \mathrm{m} 2$ \\
\cline { 2 - 4 } & $\mathrm{I} 3$ & 1,344 & $\mathrm{~kg} \cdot \mathrm{m} 2$ \\
\hline & $\mathrm{X}-0,05$ & 1,00 & 0,01 \\
\cline { 2 - 4 } & $\mathrm{Y}-0,54$ & $-0,04$ & 0,8 \\
\cline { 2 - 4 } & $\mathrm{Z} 0,84$ & 0,04 & 0,54 \\
\hline
\end{tabular}

Satelit LAPAN-TUBSAT yang berbentuk kotak dengan berat 57 kilogram dan dimensi 45 x 45 x 27 sentimeter ini akan digunakan untuk melakukan pemantauan langsung situasi di 
Bumi seperti kebakaran hutan, gunung berapi, banjir, menyimpan dan meneruskan pesan komunikasi di wilayah Indonesia, serta untuk misi komunikasi bergerak.

LAPAN-TUBSAT membawa sebuah kamera beresolusi tinggi dengan daya pisah 5 meter dan lebar sapuan 3.5 kilometer di permukaan bumi pada ketinggian orbit 630 kilometer serta sebuah kamera resolusi rendah berdaya pisah 200 meter dan lebar sapuan 81 kilometer. Manuver attitude ini dilakukan dengan menggunakan attitude control system yang terdiri atas 3 reaction wheel, 3 gyro, 2 sun sensor, 3 magnetic coil dan sebuah star sensor untuk navigasi satelit. Komponen-komponen inilah yang membedakannya dengan satelit mikro lain yang hanya mengandalkan sistem stabilisasi semi pasif gradien gravitasi dan magneto torquer, sehingga sensornya hanya mengarah vertikal ke bawah. Sebagai satelit pengamatan, satelit ini dapat digunakan untuk melakukan pemantauan langsung kebakaran hutan, gunung meletus, tanah longsor dan kecelakaan kapal maupun pesawat.

\section{METODE PENELITIAN}

\section{Reaction Wheel}

Reaction Wheel (RW) merupakan aktuator aktif yang digunakan untuk mengatur rotasi satelit. RW bekerja berdasarkan prinsip konservasi momentum sudut, di mana perubahan kecepatan rotasi dari RW makan torsi yang dihasilkan akan mempengaruhi gerak rotasi satelit. Dalam aplikasinya, Aktuator RW tersusun atas beberapa bagian yaitu Motor DC Brushless (BLDC) sebagai penghasil torsi pada Flywheel.

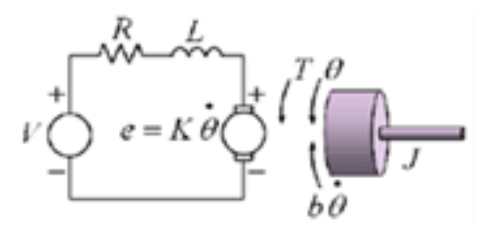

Gambar 3. Motor DC Brushless dengan Flywheel.

dalam bentuk laplace maka didapatkan fungsi transfer sebagai berikut:

$\frac{\theta(s)}{V_{a}(s)}=\frac{K_{t}}{\left(J S^{2}+B S\right)\left(R_{a}+L_{a} s\right)+K_{b} K_{t} s}$

Beban kerja dari motor dc brushless didasarkan pada reaction wheel yang terpasang pada rotor sehingga menghasilkan torsi beban kerja.

$T_{L}=I_{w} \dot{W}_{w}$

Di mana $I_{w}$ adalah momentum inersia roda dan $\dot{W}_{w}$ adalah percepatan sudut roda

Batang rotor pada motor memiliki kecepatan dan percepatan sudut yang sama dengan reaction wheel, maka:

$W_{m}=W_{w} \& \dot{W}_{w}=\dot{W}_{w}$

Persamaan kesetimbangan momentum batang rotor adalah

$I_{m} \dot{W}_{m}=T-T_{L}$

Dengan mensubtitusikan persamaan (2) dan (3) ke dalam (4) maka

$\left(I_{m}+I_{w}\right) \dot{W}_{m}=T$

Diasumsikan bahwa $I_{w}>>I_{m}$ ketika reaction wheel ditambahkan ke dalam sistem untuk menambahkan moment of inertia (MOI) sehingga menjadi

$T=I_{w} \dot{W}_{m}$

Berdasarkan persamaan (6) maka perintah torsi pada motor, kecepatan sudut dari batang rotor dapat dihitung.

\section{Dinamika Satelit}

Pergerakan orientasi dari sebuah rigid body seperti satelit dapat digambarkan oleh persamaan Euler pada wahana antariksa [14]. 
$I_{x} \omega_{x}^{\prime}+\omega_{y} \omega_{z}\left(I_{z}-I_{y}\right)=T_{x}$

$I_{\mathrm{y}} \omega_{\mathrm{y}}^{\prime}+\omega_{\mathrm{x}} \omega_{\mathrm{z}}\left(I_{\mathrm{x}}-I_{\mathrm{z}}\right)=T_{\mathrm{y}}$

$I_{\mathrm{z}} \omega_{\mathrm{z}}^{\prime}+\omega_{\mathrm{x}} \omega_{\mathrm{y}}\left(I_{\mathrm{y}}-I_{\mathrm{z}}\right)=T_{\mathrm{z}}$

Tiga buah reaction wheel yang identik ditempatkan pada sumbu principal yang mempengaruhi pergerakan orientasi. Flywheel yang digunakan memiliki momen inersia $I_{w}=912.6 \times 10^{-6} \mathrm{~kg} \cdot \mathrm{m}^{2}$ [15], dengan kecepatan rotasi dari reaction wheel adalah $\Omega_{x}, \Omega_{y}, \Omega_{z}$ pada sumbu $x, y$, dan $z$. Pengaruh dari vektor momentum sudut reaction wheel pada sistem $h_{w}^{\prime}=I_{w}\left(\Omega_{x} i+\Omega_{y} j+\Omega_{z} k\right)^{\prime}$ maka persamaannya menjadi:

$I_{x} \omega_{x}^{\prime}+\omega_{y} \omega_{z}\left(I_{z}-I_{y}\right)+I_{w}\left(\Omega_{z} \omega_{y}+\Omega_{y} \omega_{z}+\Omega_{x}^{\prime}\right)=T_{x}$

$I_{y} \omega_{y}^{\prime}+\omega_{x} \omega_{z}\left(I_{x}-I_{z}\right)+I_{w}\left(\Omega_{x} \omega_{z}+\Omega_{z} \omega_{x}+\Omega_{y}^{\prime}\right)=T_{y}$

$I_{z} \omega_{z}^{\prime}+\omega_{x} \omega_{y}\left(I_{y}-I_{x}\right)+I_{w}\left(\Omega_{y} \omega_{x}+\Omega_{x} \omega_{y}+\Omega_{z}^{\prime}\right)=T_{z}$

\section{HASIL DAN PEMBAHASAN}

Kendali PID digunakan dalam pengendalian reaction wheel karena banyak digunakan dan mudah dalam implementasinya. Gambar 4 adalah sistem pengendalian reaction wheel lingkar terutup dengan sinyal error merupakan nilai kecepatan sudut dari reaction wheel sehingga kecepatan sudut yang diinginkan adalah W_des=W_ref-W_m

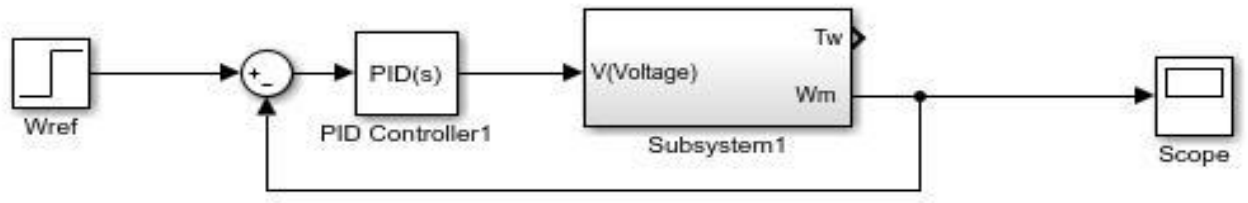

Gambar 4. Sistem pengendalian reaction wheel lingkar tertutup

Kendali PID membutuhkan P, I, dan D sebagai parameter kendalinya, tuning dilakukan untuk mendapatkan parameter P, I, dan D yang optimal. Ada banyak metode tuning, antara lain: Cohen-Coon, Ziegler- Nichols.

Parameter kendali PID ditentukan menggunakan algoritma genetika. Algoritma genetika telah banyak digunakan untuk tuning kendali PID. Adapun parameter yang digunakan pada penalaan kendali PID terdapat pada tabel 2 dipilih secara acak.

Tabel 2. Parameter Algoritma Genetika

\begin{tabular}{|l|l}
\hline Populasi awal & 200 \\
\hline Laju crossover & 0.9 \\
Konstanta mutasi & 0.7 \\
Kriteria penghenti & $\begin{array}{l}50 \text { Generasi, } \\
\text { error } 10^{\wedge}-4\end{array}$ \\
\hline
\end{tabular}

Tuning PID dilakukan oleh Algoritma Genetika dengan parameter sesuai tabel 2, maka didapati parameter P, I, D seperti pada tabel 3 .

Tabel 3. PID-AG

\begin{tabular}{|l|c}
\hline Parameter PID & Nilai \\
\hline Proporsional & 9.983 \\
Integral & 0.938 \\
Derivatif & -9.99 \\
\hline
\end{tabular}

Simulasi dinamis satelit menggunakan program MATLAB dengan platform Smart Nanosatellite Attitude Propagator (SNAP). SNAP merupakan 6-DOF propagator orientasi satelit yang diimplementasikan pada MATLAB dan Simulink yang dapat digunakan untuk menganalisa pengaruh lingkungan terhadap torsi pada sebuah satelit dan mendesain serta menganalisa teknik stabilisasi pasif orientasi satelit, seperti Passive Magnetic Stabilization dan Gravity Gradient Stabilization. Pada versi terbarunya, pengguna SNAP diberikan keleluasaan untuk menambahkan sistem ADCS. 


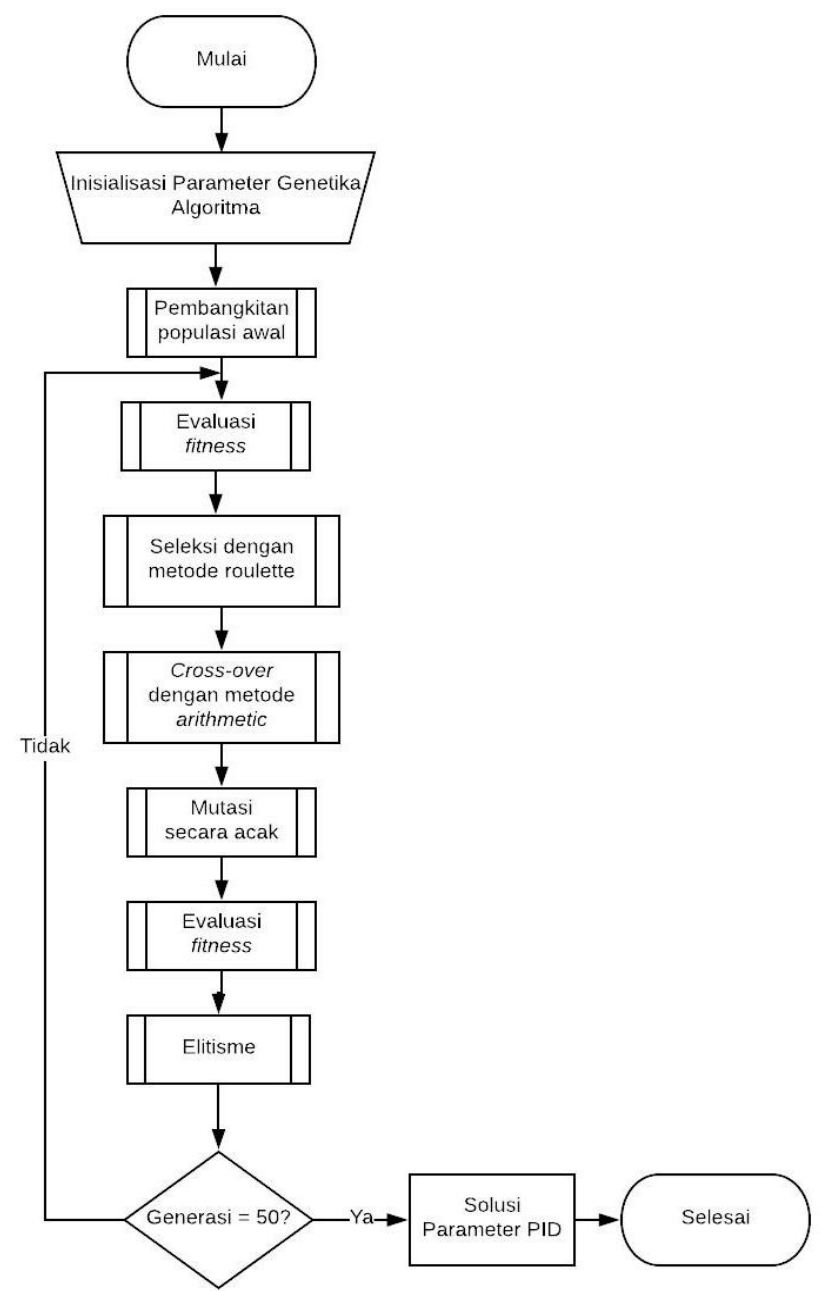

Gambar 5. Diagram alir optimasi algoritma genetika.

Seperti tampak pada gambar 6, terdapat beberapa bagian yaitu Orbital Information, Satellite Description, dan Simulation Parameters. Pada bagian orbital information, dimasukan informasi orbit dari satelit yang dikendaki. Pengguna dapat memasukan data Two-Line Element (TLE) dengan mudah. Pada satellite description berguna untuk memasukan informasi yang berkaitan dengan spesifikasi satelit. Simulation Parameters memuat parameter yang digunakan dalam simulasi, seperti lamanya simulasi dan inisial rotasi (tumbling).

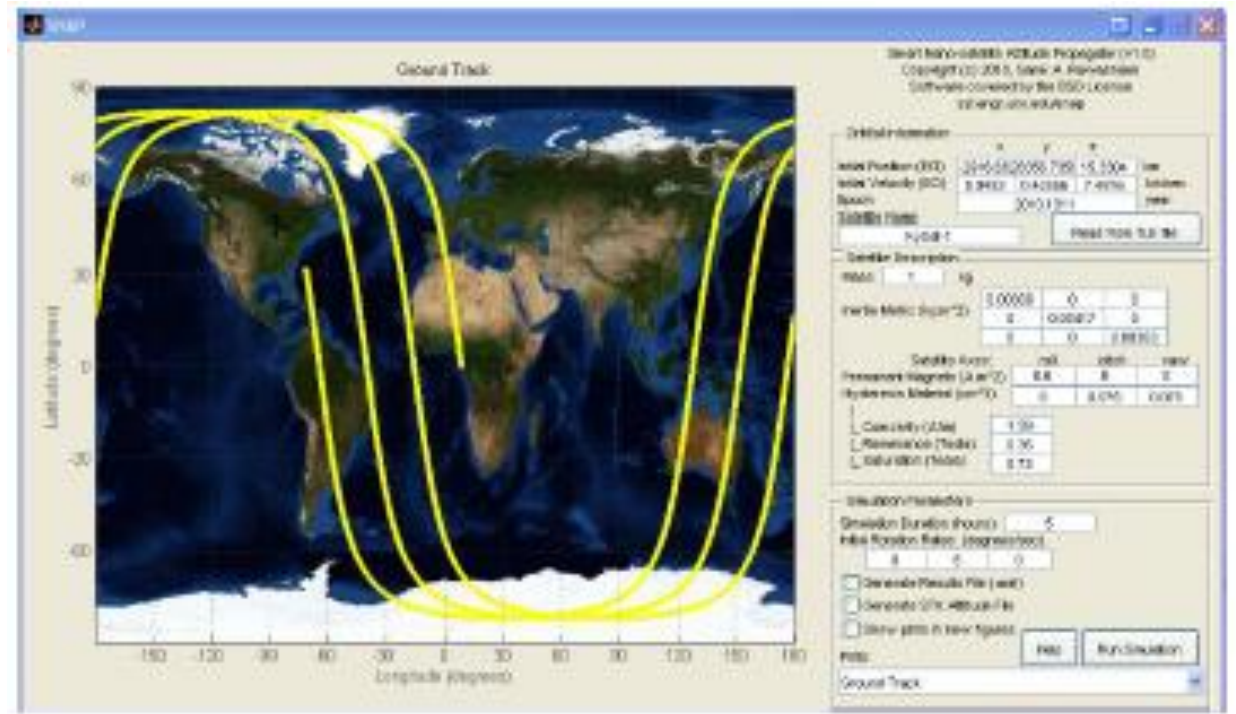

Gambar 6. Antarmuka SNAP. 
Pada simulasi ini, reaction wheel yang digunakan sebanyak 3 buah untuk masing-masing sumbu $\mathrm{x}, \mathrm{y}, \mathrm{z}$ sehingga blok diagramnya seperti pada gambar 5 dengan keluaran berupa torsi untuk tiap sumbu.
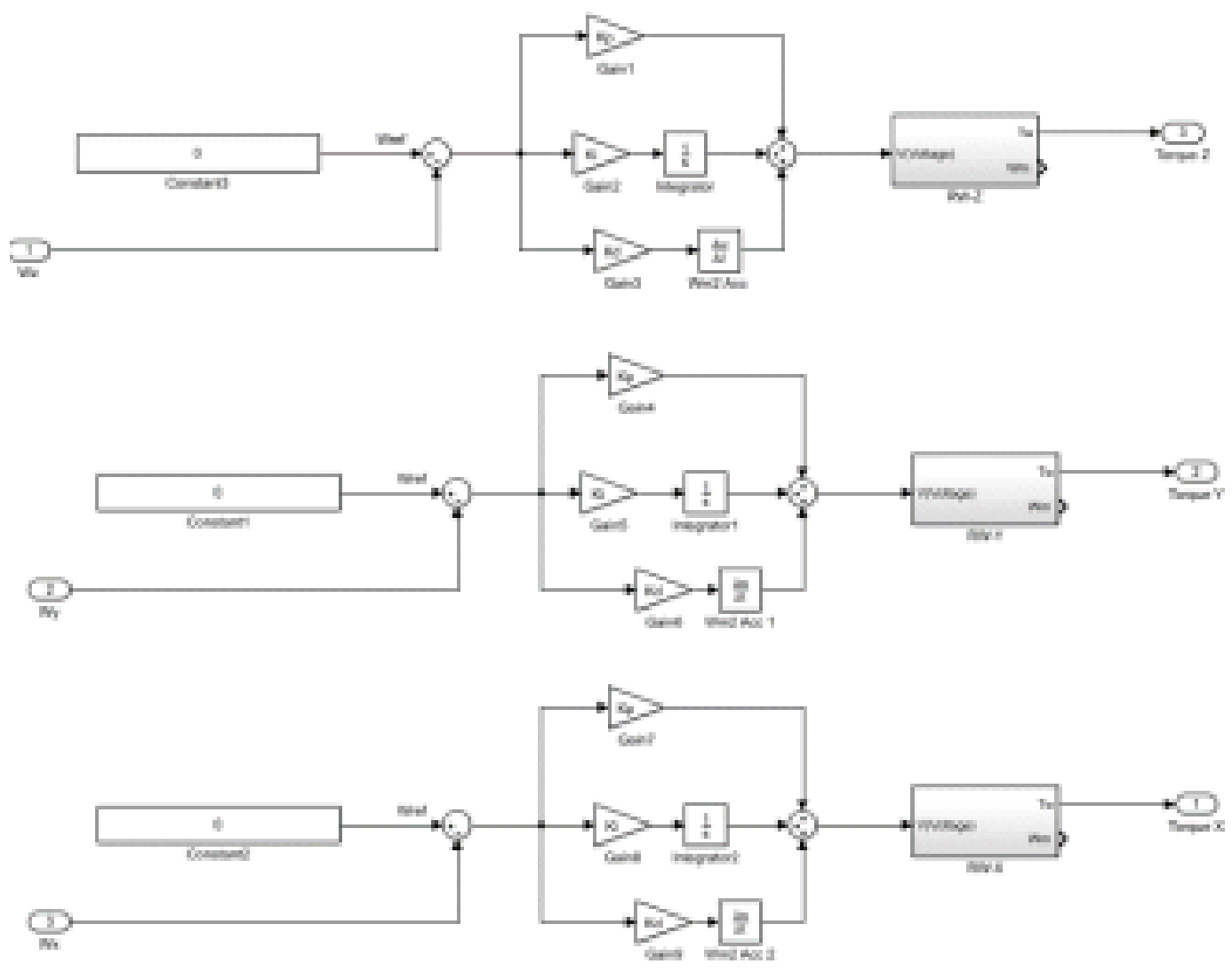

Gambar 7. 3-Axis Reaction Wheel

Simulasi yang dilakukan menskenariokan bahwa satelit dalam keadaan tumble memiliki kecepatan sudut, dalam simulasi ini yaitu $\left[\begin{array}{lll}2 & 2 & 2\end{array}\right]^{\circ} /$ detik yang kemudian dilakukan detumbling yaitu membuat kecepatan sudut satelit menjadi $\left[\begin{array}{lll}0 & 0 & 0\end{array}\right]^{\circ} /$ detik. Maka didapatkan grafik seperti pada gambar 9 .

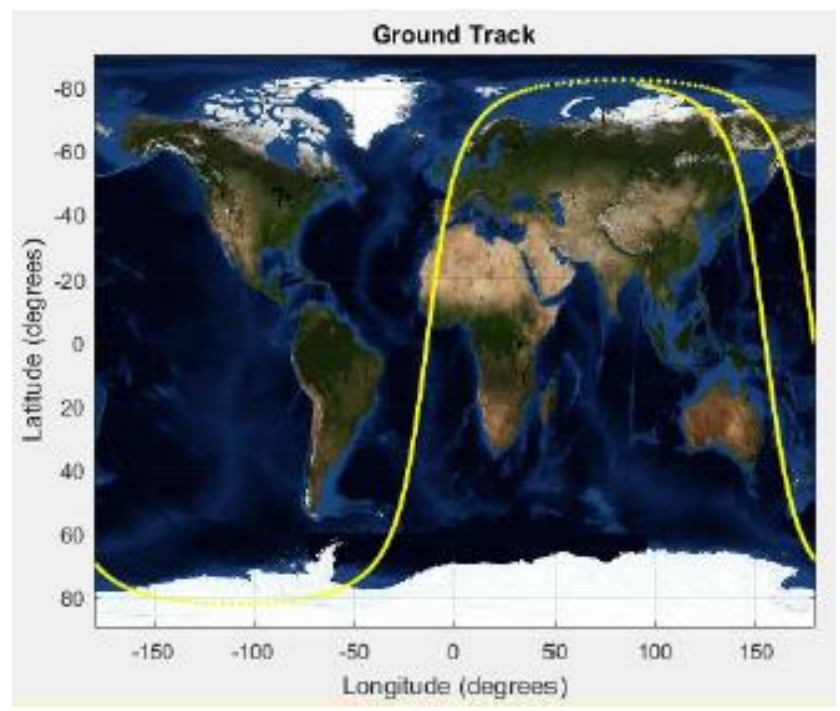

Gambar 8. Ground track.

Simulasi dilakukan menggunakan simulator SNAP dengan waktu simulasi satu putaran orbit satelit LAPAN TUBSAT A1 yaitu selama 4 jam. Simulasi yang dilakukan menskenariokan bahwa satelit dalam keadaan tumble yaitu ketika satelit memiliki inisial kecepatan sudut tertentu, kemudian dilakukan detumbling yaitu membuat kecepatan sudut 
satelit menjadi $\left[\begin{array}{lll}0 & 0 & 0\end{array}\right]^{\%}$ detik. Penelitian ini mensimulasikan keadaan tumble yaitu dengan inisial kecepatan sudut $[0,50,50,5]^{\circ}$ detik. Nilai yang kurang dari 0 atau minus (-) menunjukan pergerakan dengan arah yang berlawanan dari nilai lebih dari 0 atau plus (+). Dari gambar 7 dapat dilihat bahwa pada waktu antara 50 dan 100 menit satelit mengalami peningkatan kecepatan sudut. Pada sumbu roll nilai kecepatan sudut terbesarnya adalah $19,65^{\circ}$ detik di menit 85 . Sumbu pitch memiliki nilai kecepatan sudut terbesarnya adalah $3,33 \%$ detik di menit 86 . Dan sumbu yaw memiliki nilai kecepatan sudut terbesarnya yaitu $13,56 \%$ detik di menit 85 . Kemudian semua sumbu mengalami perlambatan kecepatan sudut. Nilai kecepatan sudut satelit yang didapat pada akhir simulasi yaitu $[-0,3-0$ $1,2]^{\circ} /$ detik.

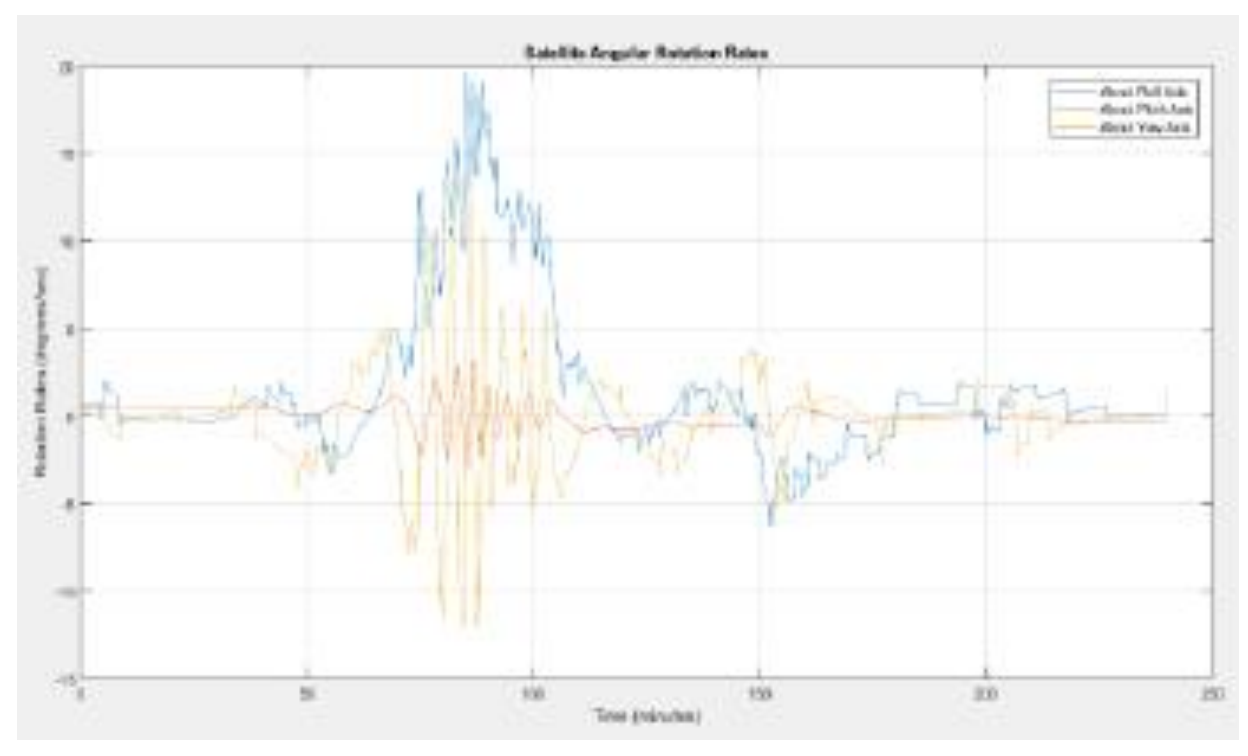

Gambar 9. Kecepatan Sudut Satelit

Nilai error pada lingkar tertutup reaction wheel adalah nilai kecepatan sudut yang dihasilkan oleh reaction wheel dikurangi dengan nilai kecepatan sudut yang dikehendaki atau dapat ditulis $W_{\text {error }}=W_{\text {ref }}-W_{m}$.

\section{KESIMPULAN}

Dari penelitian yang telah dilakukan dapat disimpulkan algoritma genetika dengan populasi awal sebanyak 200 populan, laju crossover 0.8 , konstanta mutasi 0.01 kriteria penghenti adalah 50 generasi dengan fitness function berdasarkan indeks performansi PID yaitu ITAE telah menghasilkan nilai $\mathrm{P}, \mathrm{I}$, dan D untuk sebuah reaction wheel yaitu Proporsional (P) 9.983, Integral (I) 0.938, dan Derivatif (D) -9.99 dengan indeks performansi ITAE sebesar 481.9479. Berdasarkan grafik respon 3-axis reaction wheel, kendali PID yang teroptimasi algoritma genetika yang didapatkan cukup baik karena nilai kecepatan sudut yang dihasilkan sesuai dengan nilai setpointnya dengan rata-rata W_error untuk kesemua sudut memiliki nilai dibawah $1 \mathrm{rad} / \mathrm{s}$. Subsistem ADCS satelit tidak hanya mengendalikan aktuator aktif melainkan melibatkan pengendalian dinamis satelit sehingga dapat memberikan estimasi nilai yang tepat yang dibutuhkan oleh satelit untuk kemudian dihasilkan oleh aktuator.

\section{DAFTAR PUSTAKA}

[1] "What Is a Satellite?," National Aeronautics and Space Administration, 8 February 2018. [Online]. Available: https://www.nasa.gov/audience/forstudents/k4/stories/nasa-knows/what-is-a-satellite-k4.html. [Accessed 5 March 2018].

[2] S. R. Starin, Attitude Determination and Control Systems, Microcosm, 2010.

[3] N. Imroatul and H. Nurhadi, "Komparasi Sistem Kontrol Satelit (ADCS) dengan Metode Kontrol PID dan Sliding-PID," Jurnal Teknik POMITS, vol. I, no. 1, 2012. 
[4] S. Li, J. Yuan, J. Luo and W. Ma, "Satellite Attitude Control through Evolving a Neural Network," in International Conference on Mechatronics and Automation, Xi'an, 2010.

[5] "Types of Orbits," European Space Agency, 17 April 2017. [Online]. Available: https://www.esa.int/Our_Activities/Space_Transportation/Types_of_orbits. Accessed 6 March 2018].

[6] H. Riebeek, "Catalog of Earth Satellite Orbits," Earth Observatory, National Aeronautics and Space Administration, 4 September 2009. [Online]. Available: https://earthobservatory.nasa.gov/Features/OrbitsCatalog/. [Accessed 6 March 2018].

[7] R. Mohsenipour, H. Nemati and dkk, "Attitude Control of a Flexible Satellite by Using Robust Control Design Methods," Intelligent Control and Automation, vol. 4, no. 3, 2013.

[8] R. E. Kalman, A New Approach to Linear Filtering and Prediction Problems, Baltimore: Research Institute for Advance Study, 1960.

[9] K. J. Astrom and T. Hugglund, PID Controllers: Theory, Design, and Tuning, Instrument Society of America, 1995.

[10] S. Kusumadewi, Artificial Intelligence (Teknik dan Aplikasinya), Yogyakarta: Graha Ilmu, 2003. Te-Chin Jan, “(12) United States Patent,” US 6285630 B1, 2002.

[11] E. Stella Ogochukwu, A. Desmond Okechukwu, and O. Godfrey Nnaegbo, "Construction And Testing Of Ultrasonic Bird Repeller," J. Nat. Sci. Res. www.Online), vol. 2, no. 9, pp. 2225-921, 2012.

[12] I. Buyung and A. W. Soejono, "Area Persawahan Dengan Menggunakan Gelombang Ultrasonik Berbasis Mikrokontroler Atmega168," pp. 121-134, 2012.

[13] A. E. Waluyo et al., "Rancang Bangun Prototype Panel Surya Sebagai Alat," pp. 14, 2010.

[14] S. Trajectory, P. Dan, F. Pada, and R. Obstacle, "Journal of Control and Network Systems," vol. 4, no. 1, pp. 31-38, 2015.

[15] Y. A. Zulfiadi, "Prototype Alat Pengusir Hama Burung Berbasis Mikrokontroler Atmega8," 2012.

[16] C. F. Nome and F.- Sensore, "FC-04 Sensore Schede sensori,"2-5, 2014.

[17] Tatsuro Baba, "Time-Frequency Analysis Using Short Time Fourier Transform," Open Acoust. J., vol. 5, pp. 32-38, 2012.

[18] A. G. De Oliveira et al., "Bird acoustic activity detection based on morphological filtering of the spectrogram," Appl. Acoust., vol. 98, pp. 34-42, 2015. 